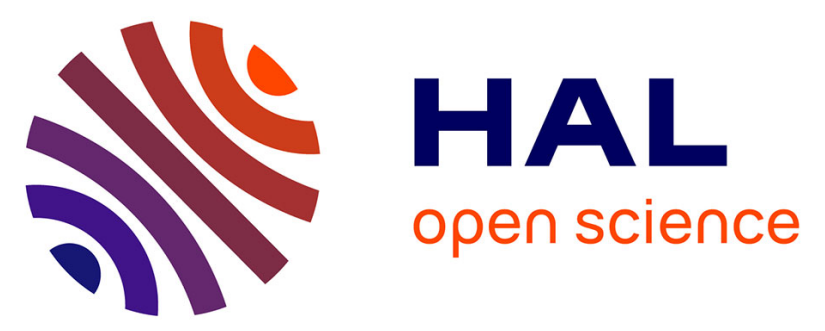

\title{
Changes in foraging mode caused by a decline in prey size have major bioenergetic consequences for a small pelagic fish
}

\author{
Elisa Thoral, Quentin Queiros, Damien Roussel, Gilbert Dutto, Eric Gasset, \\ David J Mckenzie, Caroline Romestaing, Jean-marc Fromentin, Claire Saraux, \\ Loïc Teulier
}

\section{To cite this version:}

Elisa Thoral, Quentin Queiros, Damien Roussel, Gilbert Dutto, Eric Gasset, et al.. Changes in foraging mode caused by a decline in prey size have major bioenergetic consequences for a small pelagic fish. Journal of Animal Ecology, 2021, 90, pp.2289-2301. 10.1111/1365-2656.13535 . hal-03234605

\section{HAL Id: hal-03234605 \\ https://hal.science/hal-03234605}

Submitted on 25 May 2021

HAL is a multi-disciplinary open access archive for the deposit and dissemination of scientific research documents, whether they are published or not. The documents may come from teaching and research institutions in France or abroad, or from public or private research centers.
L'archive ouverte pluridisciplinaire HAL, est destinée au dépôt et à la diffusion de documents scientifiques de niveau recherche, publiés ou non, émanant des établissements d'enseignement et de recherche français ou étrangers, des laboratoires publics ou privés. 


\section{Changes in foraging mode caused by a decline in prey size have major bioenergetic consequences for a small pelagic fish}

Elisa Thoral ${ }^{1}$, Quentin Queiros ${ }^{2}$, Damien Roussel ${ }^{1}$, Gilbert Dutto ${ }^{3}$, Eric Gasset ${ }^{4}$, David J. McKenzie ${ }^{5}$, Caroline Romestaing ${ }^{1}$, Jean-Marc Fromentin ${ }^{2}$, Claire Saraux ${ }^{2,6}$ and Loïc Teulier ${ }^{1}$.

${ }^{1}$ Univ Lyon, Université Claude Bernard Lyon 1, CNRS, ENTPE, UMR 5023 LEHNA, F-69622, Villeurbanne, France

${ }^{2}$ MARBEC, Univ Montpellier, CNRS, IFREMER, IRD, Sète, France

${ }^{3}$ Ifremer (Institut Français de Recherche pour l'Exploitation de la MER), Laboratoire SEA, Chemin de

Maguelonne, 34250 Palavas-Les-Flots, France

${ }^{4}$ MARBEC, Univ Montpellier, CNRS, IFREMER, IRD, Palavas-Les-Flots, France

${ }^{5}$ MARBEC, Univ Montpellier, CNRS, IFREMER, IRD, Montpellier, France

${ }^{6}$ IPHC, UMR7178, Université de Strasbourg, CNRS, 67000 Strasbourg, France

Corresponding author: Loïc TEULIER, Université de Lyon, UMR 5023 Ecologie des Hydrosystèmes Naturels et Anthropisés, Université Lyon 1, ENTPE, CNRS, F-69622 Villeurbanne, France, loic.teulier@univ-lyon1.fr

Authors' contributions: QQ, J-MF, GD, EG, DMK, DR, CS and LT conceived and designed the study. ET, QQ, GD, EG, DR, CR, DMK, CS and LT carried out the study. GD \& EG took care of the fish and participated to the experimental protocol. ET, QQ, DR, DMK, CS and LT analyzed the data and drafted the manuscript. All authors reviewed and revised the article critically and approved the final version.

Acknowledgements: This study was funded through the MONALISA project, financed by the European Union and the French Ministry of Agriculture through the European Maritime and Fisheries Fund (EMFF/FEAMP) as well as France Filière Pêche. Experimental procedures were approved by the ethics committee for animal experimentation $n^{\circ} 036$ of the French Ministère de l'Enseignement Supérieur, de la Recherche et de l'Innovation, with reference number APAFIS $n^{\circ} 7097-2016093008412692$. We warmly thank the reviewers for their constructive remarks and comments on the manuscript. 
Data availability statement: Data available from the Dryad Digital Repository:

\section{Abstract}

1. Global warming is causing profound modifications of aquatic ecosystems and one major outcome appears to be a decline in adult size of many fish species. Over the last decade, sardine populations in the Gulf of Lions (NW Mediterranean Sea) have shown severe declines in body size and condition as well as disappearance of the oldest individuals, which could not be related to overfishing, predation pressure or epizootic diseases.

2. In this study, we investigated whether this situation reflects a bottom-up phenomenon caused by reduced size and availability of prey that could lead to energetic constraints. We fed captive sardines with food items of two different sizes eliciting a change in feeding mode (filter-feeding on small items and directly capturing larger ones) at two different rations for several months, and then assessed their muscle bioenergetics to test for changes in cellular function.

3. Feeding on smaller items was associated with a decline in body condition, even at high ration, and almost completely inhibited growth by comparison to sardines fed large items at high ration.

4. Sardines fed on small items presented specific mitochondrial adjustments for energy sparing, indicating a major bioenergetic challenge. Moreover, mitochondria from sardines in poor condition had low basal oxidative activity but high efficiency of ATP production. Notably, when body condition was below a threshold value of 1.07 , close to the mean observed in the wild, it was directly correlated with basal mitochondrial activity in muscle.

5. The results show a link between whole-animal condition and cellular bioenergetics in 
the sardine, and reveal physiological consequences of a shift in feeding mode. They demonstrate that filter-feeding on small prey leads to poor growth, even under abundant food and an increase in the efficiency of ATP production. These findings may partially explain the declines in sardine size and condition observed in the wild.

62

63 Keywords: Bioenergetics, red muscle, mitochondria, fish shrinking, sardine, foraging 64 behaviour, food restriction 


\section{Résumé}

66 Le changement global entraîne de profondes modifications des écosystèmes aquatiques, l'une

67 des principales étant le déclin de la taille des adultes chez de nombreuses espèces de poissons.

68 Au cours de la dernière décennie, les populations de sardines du Golfe du Lion (Nord-Ouest de

69 la Méditerranée) ont montré une importante diminution de leur taille et de leur condition

70 corporelle ainsi qu'une disparition des individus les plus âgés, qui n'ont pas pu être liées à la

71 surpêche, à la pression de prédation ou aux épizooties.

72 Dans cette étude, nous avons cherché à savoir si cette situation reflète un phénomène ascendant

73 causé par la réduction de la taille et de la disponibilité des proies qui pourrait entraîner des

74 contraintes énergétiques chez la sardine. Nous avons ainsi nourri des sardines captives avec des

75 granulés de deux tailles différentes provoquant un changement de mode d'alimentation

76 (filtration des petits granulés et capture directe des plus gros) et à deux rations différentes

77 pendant plusieurs mois, puis nous avons évalué leur bioénergétique musculaire pour tester les

78 changements au niveau de leur fonction cellulaire.

79 L'alimentation à base de petits granulés a été associée à un déclin de la condition corporelle,

80 même à une ration élevée, et à une croissance quasiment inhibée par rapport aux sardines

81 nourries avec des plus gros granulés à une ration élevée.

82 Les sardines nourries avec des petits granulés ont également présenté des ajustements 83 mitochondriaux spécifiques pour économiser de l'énergie, indiquant un défi bioénergétique majeur. De plus, les mitochondries des sardines en mauvaise condition présentaient une faible activité oxydative basale, mais une efficacité élevée de production d'ATP. Notamment, lorsque la condition corporelle était inférieure à une valeur seuil de 1,07, proche de la moyenne observée

87 dans la nature, elle était directement corrélée à l'activité mitochondriale basale dans le muscle.

88 Ces résultats montrent un lien entre la condition de l'animal entier et la bioénergétique cellulaire 89 chez la sardine, et révèlent les conséquences physiologiques d'un changement de mode 90 d'alimentation. Ils démontrent que le nourrissage via la filtration de petites proies entraîne une 91 faible croissance, même en cas de nourriture abondante, et une augmentation de l'efficacité de 92 la production d'ATP. Ces résultats peuvent expliquer en partie le déclin de la taille et de la 93 condition des sardines observé dans la nature. 


\section{Introduction}

Marine ecosystems face strong pressures from a combination of climate forcing, anthropogenic disturbance (pollution, navigation, recreational activities, by-catch, climate change) and anthropogenic competition for resources (e.g. fisheries) (Halpern et al., 2008), all of which can impact organismal phenotypes. While water warming and a relaxation of densitydependence phenomena through fishing should promote an increase in growth rates of ectothermic organisms (Morrongiello, Sweetman, \& Thresher, 2019), there is evidence that the final adult size of many aquatic ectotherms is declining globally (Daufresne, Lengfellner, \& Sommer, 2009; Forster, Hirst, \& Atkinson, 2012). Whereas recently debated (Audzijonyte $e t$ al., 2020), this size reduction occurs within and amongst species, throughout the food web, from top predators (Sibert et al., 2006) to primary producers (Sommer, Paul, \& MoustakaGouni, 2015). The decrease in size could result from fishery-induced evolution (as fisheries targeting mostly larger organisms should favour the selection of slow growth and smaller phenotypes, Conover \& Munch, 2002; Jørgensen et al., 2007) and/or from within-generation plastic physiological responses. It could also result from direct effects of warming on physiology (e.g. the temperature-size rule; Atkinson, 1994) or global-change-derived modifications of primary production (Bopp et al., 2013).

There has been a profound decline in size and body condition of sardines Sardina pilchardus and anchovies Engraulis encrasicolus in the Gulf of Lions (northwestern Mediterranean Sea), due to lower growth and disappearance of larger and older individuals (Brosset et al., 2017; Van Beveren et al., 2014). Extensive research has established that this is not due to top-down effects, such as predation or fishing pressure, nor to pathogens (reviewed in Saraux et al., 2019). Rather, a bottom-up process appears to be at play, linked to a shift in plankton communities that the fishes feed upon, towards smaller zooplankton species (Brosset et al., 2016a; Queiros et al., 2019). When maintained in captivity on artificial feeds, wild 
119 sardines exhibited high growth rates and condition, indicating that the decline in size and condition was a plastic rather than an evolutionary response (Saraux et al., 2019). While it is obvious that food quantity can have a significant impact on growth and body condition in fishes

122 (Lee et al., 2018; Sun \& Chen, 2009), the potential implications of prey size are less well 123 known. They deserve to be investigated because of climate-change related regime shifts in food 124 webs (Garzke, Ismar, \& Sommer, 2015). A reduction in prey size is often accompanied by 125 lower energy content (Zarubin et al., 2014), which may present a major energetic challenge to predators, even for sardines that are opportunistic planktivores (Palomera et al., 2007; Rumolo et al., 2016).

It has been demonstrated that, for rations of similar energy content, sardines fed small prey have lower growth and condition than those fed larger prey (Queiros et al., 2019). The sardine modifies its feeding behaviour with prey size, switching from filter feeding on small prey to direct capture of larger prey, regardless of prey availability (Costalago, Garrido, \& Palomera, 2015; Garrido et al., 2007). Foraging duration was much higher for sardines fed on small food items than those fed on larger ones (Queiros et al., 2019). Thus, a possible mechanism for the poor growth and condition may relate to high energy requirements for extended swimming activity during filter-feeding, compared to shorter bouts of swimming to capture large items (Costalago \& Palomera, 2014; Crowder, 1985). being structurally separated into discrete slow-twitch oxidative 'red' muscle, used for steady aerobic swimming, and fast-twitch glycolytic 'white' muscle, used for short bursts of highspeed swimming (Bone, 1978; Webb, 1998). Muscular contraction is powered by ATP but, its 141 production depends on muscle type: while red muscle generates this aerobically by 142 mitochondrial oxidative phosphorylation using substrates and oxygen delivered in the 143 bloodstream, white muscle generates ATP mostly through anaerobic glycolysis of intracellular 
144 substrates (Fig. 1, Bone, 1978; Webb, 1998). In the sardine, swimming muscle represents up to $14570 \%$ of body mass and, although the red muscle mass only represents $\sim 10 \%$ of the body mass, 146 its mitochondrial activity accounts for $70 \%$ of muscle metabolic activity (Teulier et al., 2019).

147 Mitochondrial oxidative phosphorylation is a series of reactions that couple substrate oxidation 148 (catabolism of carbohydrates, lipids or proteins) and oxygen consumption with the generation 149 of a proton motive force, which is then used by ATP synthase to synthesize ATP (Fig. 1). A 150 significant proportion of mitochondrial oxygen consumption is not, however, coupled to ATP 151 synthesis but is used to compensate for proton leakage across the inner mitochondrial 152 membrane. Mitochondrial proton leak is a ubiquitous waste of potential energy, which reduces 153 the efficiency of ATP production (i.e. the ATP/O ratio) (Brand, 2005; Fig. 1). The ATP/O ratio 154 defines how much oxygen and nutrients are needed to meet cell ATP demands and, ultimately, 155 sustain animal performance (Brand, 2005). For instance, mitochondrial ATP/O has been 156 positively related to muscle performance (Conley et al., 2013; Distefano et al., 2018) and 157 growth efficiency (Salin et al., 2019; Toyomizu et al., 2011). Mitochondrial efficiency is also 158 flexible, varying among individuals over time, notably in response to environmental and 159 physiological constraints such as temperature, oxygen or food availability (Roussel \& Voituron, 160 2020; Salin et al., 2015; Salin et al., 2012; Thoral et al., 2021b). For example, mitochondrial efficiency can increase to enhance energy conservation during food deprivation (Bourguignon et al., 2017; Monternier et al., 2017) or decrease to promote heat generation, as in brown adipose tissue of cold-adapted mammals (Nedergaard \& Cannon, 2018). The maintenance of a high ATP/O ratio and related efficiency may carry significant costs, especially increased 165 production of reactive oxygen species (Brand, 2000), and/or a decreased carbon flux from 166 mitochondria that can compromise aspects of cellular biosynthesis (Rolfe \& Brand, 1997). 167 Overall, there is strong evidence that mitochondrial efficiency (ATP/O ratio) can be adjusted 
168 plastically, in response to metabolic constraints and energy demands, leading to a dynamic 169 interplay with the biological condition of an organism (Koch et al., 2021). In this study we investigated whether aerobic muscle energy metabolism and, in

171 particular, mitochondrial function, might represent a mechanistic nexus for how sardine 172 foraging mode impacts upon their physical condition (Fig. 1). We thus investigated the 173 oxidative activity of red muscle fibres and the coupling efficiency of mitochondrial oxidative 174 phosphorylation in sardines fed for 7 months with either small or large food items $(0.1 \mathrm{~mm}$ and $1751.2 \mathrm{~mm}$ diameter commercial pellets), at either low or high ration $(0.3 \%$ and $0.6 \%$ of fish mass 176 per day). We predicted that fish fed on small items would show specific mitochondrial 177 adjustments for energy sparing, with decreased oxygen consumption but enhanced efficiency 178 (ATP/O ratio), which would indicate that increased metabolic costs of foraging mode 179 represented an energetic challenge.

\section{Material and methods}

\subsection{Experimental conditions}

All details of the experiment can be found in Queiros et al., 2019. Briefly, wild sardines were captured off Sète (South of France) in October 2016 and brought back to the Ifremer Palavas-les-Flots research station. The mean age of sardines was 1.24 years. After acclimation and weaning onto commercial pellets, sardines were weighed, measured and marked

187 individually using RFID tags (Biolog-id, Bernay, France). Thereafter, they were distributed among 8 tanks (vol. 300L, 56-57 sardines per tank) with similar mean ( \pm SD) of mass and length 189 in each (mass: $14.1 \pm 3.2 \mathrm{~g}$; length: $11.9 \pm 0.7 \mathrm{~cm}$ ). A 7-month feeding experiment was 190 performed, from $14 / 11 / 2016$ to $15 / 6 / 2017$, with natural photoperiod and water temperature 191 (water was pumped directly from the sea). Animals were fed four times a day with commercial 192 pellets (except on weekends where one daily meal was provided). The experiment included the 
reproductive season, which occurs once a year between December and March. As detailed in Queiros et al., 2019, the daily weight gain of sardines in natura was $0.2 \%$ with good condition and $0.1 \%$ with bad condition. A preliminary study found that these growth rates were achieved with daily feeding rates of $0.6 \%$ and $0.3 \%$ of fish mass. Thus, the combination of two pellet sizes $(0.1 \mathrm{~mm}$ and $1.2 \mathrm{~mm}$, within the natural range of sardine prey size) (Le Bourg et al., 2015) and two rations $(0.3 \%$ and $0.6 \%$ of fish biomass per day) resulted in four treatments: (1) small items in small quantity (SI-SQ), (2) small items in large quantity (SI-LQ), (3) large items in small quantity (LI-SQ), (4) large items in large quantity (LI-LQ). The two sizes elicited two distinct foraging modes, filtration $v s$. particulate capture (Queiros et al., 2019). Each treatment was randomly assigned to two tanks for replicates. Biometries were performed each month to correct food quantity against increasing biomass, adjusted each week based on linear extrapolation of biomass across successive biometries.

\subsection{Sardine sacrifices and morphometric measurements}

At the end of the experiment, 1 or 2 sardines were randomly removed from each tank every day over a period of 1 week, i.e. 11 to 12 fish per group, and killed by an overdose of benzocaine (1000 ppm). Sardines were fasted for 24h before euthanasia. Mass and size of each sardine were recorded. Intramuscular fat was estimated by fatmeter (Distell Fish Fatmeter MFM-992, as described in Brosset et al., 2015a) and sex was determined visually. Experiments were performed in June when sardines were out of the breeding season (Brosset et al., 2016b). Cumulative growth was estimated based on the increase in size divided by the experiment duration ( $\mathrm{mm} /$ day), and the relative growth (in \%) was calculated as follows:

$$
\text { Relative growth }=\frac{\text { Final size }- \text { Initial size }}{\text { Initial size }}
$$

Where initial and final sizes are expressed in $\mathrm{mm}$. 
et al., 2015b (based on more than 24,000 wild sardines sampled over the last 50 years):

$$
K_{n}=\frac{B M}{0.00607 \times T L^{3.057}}
$$

where TL is the total length $(\mathrm{cm})$ and BM is the wet body mass $(\mathrm{g})$. This index compares the actual wet mass of an individual to the mass predicted by the relationship of mass to length for

222 the entire wild population. As such, $\mathrm{K}_{\mathrm{n}}<1$ (or $\mathrm{K}_{\mathrm{n}}>1$ ) means that body condition is lower (or 223 higher) than the long-term average observed in the wild population

\subsection{Mitochondrial respiration}

Oxygen consumption measurements were performed in red muscle at two levels: in muscle fibres and in isolated mitochondria. At the mitochondrial level, oxygen consumption was expressed in nmol O.min ${ }^{-1} \cdot \mathrm{mg}^{-1}$ of protein, and it was expressed in nmol O.min ${ }^{-1} \cdot \mathrm{mg}^{-1}$ of red muscle at the fibre level. The oxygen consumption was then estimated at the muscle level by multiplying the oxygen consumption obtained at the fibre level by the red muscle mass $\left(\mu \mathrm{mol}\right.$ O. $\left.\mathrm{min}^{-1}\right)$ or by the relative red muscle mass (nmol O. $\mathrm{min}^{-1} \cdot \mathrm{g}^{-1}$ of fish) (see Table 2).

\section{3.a Red muscle fibre preparation and oxidative activity}

After dissection, the total mass of red muscle was measured and a $\sim 5 \mathrm{mg}$ sample of fibres was withdrawn (Fig. 1). Fibre respiration was monitored at $20^{\circ} \mathrm{C}$ using high resolution respirometers (Oxygraph-2K, Oroboros ${ }^{\circledR}$ Instruments - WGT Austria) in air-saturated respiration buffer (Mir05: $110 \mathrm{mM}$ sucrose, $0.5 \mathrm{mM}$ EGTA, $3 \mathrm{mM} \mathrm{MgCl}$, $60 \mathrm{mM} \mathrm{K}$ lactobionate, $20 \mathrm{mM}$ taurine, $10 \mathrm{mM} \mathrm{KH2PO} 4,1 \mathrm{~g} / \mathrm{L}$ fatty acid-free bovine serum albumin and $20 \mathrm{mM}$ Hepes, $\mathrm{pH}$ 7.1) using different combination of respiratory substrates $(5 \mathrm{mM}$ glutamate $/ 2.5 \mathrm{mM}$ malate; $40 \mu \mathrm{M}$ palmitoyl-carnitine $/ 2.5 \mathrm{mM}$ malate; $5 \mathrm{mM}$ pyruvate $/ 2.5 \mathrm{mM}$ malate/5 mM succinate) with a protocol adapted from Teulier et al., 2019. These different 
combinations of substrates enabled us to assay mitochondrial respiration using substrates derived from amino acid (glutamate), carbohydrate (pyruvate) and lipid (palmitoyl-carnitine) metabolic pathways. In addition, the mixture of $\mathrm{NADH}$ - and $\mathrm{FADH}_{2}$-linked substrates (pyruvate/malate and succinate) allowed a full activation of mitochondrial oxidative activity by providing electrons to complex I and complex II of the electron transport system (ETS). Phosphorylating respiration was then initiated by adding $1 \mathrm{mM}$ ADP, and the integrity of mitochondria within muscle fibres was subsequently tested by adding $10 \mu \mathrm{M}$ cytochrome $\mathrm{c}$. Finally, a sequential addition of $1 \mu \mathrm{M}$ p-trifluoromethoxy-carbonyl-cyanide-phenyl hydrazine (FCCP) was performed to measure maximal respiratory activity of the fibres.

\section{3.b Mitochondrial isolation, coupling efficiency, respiratory capacity and content}

Mitochondria were isolated from red skeletal muscle in an ice-cold isolation buffer containing (100 mM sucrose, $50 \mathrm{mM} \mathrm{KCl,} 5 \mathrm{mM}$ EDTA, $50 \mathrm{mM}$ Tris-base, $\mathrm{pH} 7.4$ at $4^{\circ} \mathrm{C}$ ), according to previously described protocol for small tissue samples (Boël et al., 2019), involving potter homogenizer, partial protease digestion, and differential centrifugation with mitochondria pelleted at $9000 \times \mathrm{g}$, all steps at $4{ }^{\circ} \mathrm{C}$. Protein content of the preparation was assayed in duplicate at 540nm using the biuret method, with bovine serum albumin as standard (Gornall et al., 1949). Absorbance of the same volume of mitochondria was also assayed at $540 \mathrm{~nm}$ in a solution containing $0.6 \% \mathrm{Na}-\mathrm{K}$-tartrate and $3 \% \mathrm{NaOH}$ and subtracted, to correct for any contamination with pigments absorbing at 540nm.

Mitochondrial oxidative phosphorylation efficiency was assessed at $20^{\circ} \mathrm{C}$ by measuring the rates of ATP synthesis and oxygen consumption in respiratory buffer $(120 \mathrm{mM} \mathrm{KCl}, 5 \mathrm{mM}$ $\mathrm{KH}_{2} \mathrm{PO}_{4}, 1 \mathrm{mM}$ EGTA, $2 \mathrm{mM} \mathrm{MgCl} 2,0.3 \%$ fatty acid-free bovine serum albumin (w/v), and $3 \mathrm{mM}$ HEPES, $\mathrm{pH}$ 7.4) supplemented with $20 \mathrm{mM}$ glucose, $1.5 \mathrm{U} / \mathrm{mL}$ hexokinase (Colinet, Renault, \& Roussel, 2017; Teulier et al., 2010). Mitochondria were energized with a mixture 
of $5 \mathrm{mM}$ pyruvate, $2.5 \mathrm{mM}$ malate, $5 \mathrm{mM}$ succinate to fully activate the ETS. ADP $(500 \mu \mathrm{M})$ was added to initiate ATP synthesis. After recording the phosphorylating respiration rate using

269 a Clark electrode (Rank Brother Ltd, Cambridge, UK), four $100 \mu \mathrm{L}$ samples of mitochondrial suspension were withdrawn from the respiratory chamber every 2 min and immediately 271 quenched in $100 \mu \mathrm{L}$ of ice-cold perchloric acid solution (10\% $\mathrm{HCLO}_{4}$ and 25mM EDTA). 272 Production of ATP was determined from the slope of the linear accumulation of glucose-6273 phosphate content over the sampling time interval (6 min) as described previously (Colinet et 274 al., 2017; Teulier et al., 2010). To make sure that ATP synthesis rate was specific to 275 mitochondrial ATP synthase activity, we determined oxygen consumption and ATP synthesis 276 rates in the presence of oligomycin $(1 \mu \mathrm{g} / \mathrm{mL})$ that inhibits mitochondrial ATP synthase. These 277 values were taken into account (i.e. subtracted from the raw ATP synthesis) to calculate the rate 278 of mitochondrial ATP synthesis (Teulier et al., 2010). Of note, the basal non-phosphorylating oxygen consumption recorded in the presence of oligomycin is a measure of the maximal rate of proton leak across the inner membrane of mitochondria. Due to the linear relationship 281 between ATP synthesis and oxygen consumption in isolated mitochondria from different tissues 282 and organisms (Beavis \& Lehninger, 1986; Fontaine et al., 1996; Nogueira et al., 2002; Roussel et al., 2015; Teulier et al., 2010), we presented these data on a single graph by drawing a linear relationship between the basal non-phosphorylating oxygen consumption activity and the maximal oxidative phosphorylation activity, which is related to maximal rates of oxygen consumption and corresponding ATP synthesis (Fig. 1B).

Maximal activity of the electron transport system (i.e. the respiratory capacity) was measured at $20^{\circ} \mathrm{C}$ by adding $2 \mu \mathrm{M}$ FCCP in the respiratory buffer supplemented with $5 \mathrm{mM}$ pyruvate, $2.5 \mathrm{mM}$ malate, $5 \mathrm{mM}$ succinate, and $1 \mu \mathrm{g} / \mathrm{mL}$ oligomycin. Mitochondrial content of skeletal muscle was estimated from the ratio between the maximal oxygen consumption rates 
of muscle fibres (expressed per gram of muscle) and mitochondria (expressed per milligram of protein).

\subsection{Statistical analyses}

Linear mixed-models (LMM) were used to evaluate the effects of food size and quantity on phenotypic traits, red muscle mitochondrial respiration and efficiency. These models all followed a similar structure, with food size and quantity as well as their interaction as fixed effects, while sex was included as a random effect to remove any potential bias associated to differences between males and females. When an interaction between size and quantity of items was significant $(P<0.05)$ or tended to be significant $(P<0.07)$, post-hoc tests comparing all four treatments (lsmeans) were performed. When the interaction was not significant, it was removed from the model and the p- values obtained in the simplified model were reported in the results section.

The relationship between individual body condition and basal mitochondrial respiration was analysed by piecewise linear regression (Fig. 3). Once the breakpoint was estimated, linear regressions were evaluated over each segment of condition (i.e. before and after the breakpoint).

Data are presented as means \pm SE. Sample sizes varied among models because some data were missing for some fish, or at the fibre level, data were removed from analyses if addition of cytochrome c caused oxygen consumption to increase by $30 \%$ or more (see 2.3.a).

Statistical analyses were performed in $R$ v. 3.6.1. with the packages lme 4 and lsmeans.

\section{Results}

\subsection{Effect of food size and quantity on body condition and growth}

For the effect of food size and quantity on body condition, fat content, growth and final mass, the interaction between size and quantity was always significant or close to significance 
(LMMs: $P=0.025-0.061)$. LI-LQ sardines showed the highest body condition, fat content, body mass, cumulative and relative growth compared to the other three groups (post-hoc lsmeans: $P$ $<0.010$ ), while LI-SQ, SI-LQ and SI-SQ did not differ significantly (Table 1). By contrast, there was no interaction between food size and quantity for effects on red muscle mass, whether in absolute terms $(\mathrm{F}=2.359 ; P=0.133, \mathrm{n}=9)$ or relative to body mass $(\mathrm{F}=0.002 ; P=0.962$, $\mathrm{n}=9)$. Still, LI sardines had greater absolute red muscle mass than SI sardines $(\mathrm{F}=15.152 ; P$ $<0.001)$, as did LQ compared to SQ sardines $(\mathrm{F}=4.551 ; P=0.039)$. Finally, the size of items also had an effect on relative red muscle mass $(\mathrm{F}=16.515 ; P<0.001)$ with LI sardines being higher than SI (Table 1).

\subsection{Oxidative metabolism at different levels of organisation}

The phosphorylating respiration state of skeletal muscle fibres obtained with different substrates is presented in Supplementary Material (Figure S1). Apart from glutamate/malate, there was no effect of food size, quantity or their interaction on the phosphorylating state of fibres (all $P>0.05$ ). Regarding glutamate/malate, the interaction between food size and quantity tended to be significant $(\mathrm{F}=3.614, P=0.066)$, and muscle phosphorylating respiration was affected by food size $(\mathrm{F}=4.220, P=0.048$, post-hoc tests: SI-LQ $<$ LI-LQ, $P=0.040)$.

Table 2 reports the maximal respiration state following addition of FCCP, as measured in isolated mitochondria and muscle fibres, and further estimated in whole red muscle and fish. Maximal respiration of isolated mitochondria was only affected by food size $(\mathrm{F}=9.334 ; P=$ 0.004), and was significantly higher in LI than in SI sardines (Table 2). Similarly, mitochondrial content was only affected by food size $(\mathrm{F}=4.604 ; P=0.040)$ but in an opposite direction, being significantly lower in LI groups. The interaction between food size and quantity was close to significance $(\mathrm{F}=3.228 ; P=0.082)$, suggesting that the negative effect of food size on mitochondrial content was mostly observed in sardines fed in small quantity. At the fibre level, 
while the interaction between food size and quantity was significant for the maximal respiration state measured at this level $(\mathrm{F}=6.697 ; P=0.014)$, no differences in fibre respiration were highlighted among groups. Finally, the food treatments had no effect on maximal respiration rates at the red muscle or whole fish level ( $P>0.05$ for size, quantity, and its interaction).

\subsection{Mitochondrial oxidative phosphorylation efficiency}

At the mitochondrial level, there was no interaction between food size and quantity on oxidative phosphorylation activity (i.e. the rates of oxygen consumption and associated ATP synthesis). However, activity was higher in sardines fed large food items (oxygen consumption: $\mathrm{F}=9.807 ; P=0.003 ;$ ATP production: $\mathrm{F}=10.638 ; P=0.002)$, regardless of quantity $(P>0.05$, Fig. 2A). Basal non-phosphorylating respiration state measured in the presence of oligomycin (i.e. the intercept with the $\mathrm{x}$-axis) was also significantly higher in LI sardines $(\mathrm{F}=11.746 ; \mathrm{P}=$ 0.002, see box in Fig. 2A). There was no significant interaction of size and quantity, and no effect of size or quantity on the slopes of the relationships between rates of ATP synthesis and oxygen consumption (Size*Quantity: $\mathrm{F}=0.014 ; P=0.906 ;$ Size: $\mathrm{F}=0.784 ; P=0.382$; Quantity: $\mathrm{F}=2.017 ; P=0.164)$. Thus, these slopes were similar between SI and LI sardines (Slope sr: $3.19 \pm 0.15$; Slope LI: $3.03 \pm 0.10$ ). Altogether, these results indicate that the regression line relating ATP synthesis to oxygen consumption was shifted to the right in LI compared to SI groups, meaning that mitochondria from LI sardines had to consume more oxygen to produce the same amount of ATP, due to a higher basal non-phosphorylating respiration or "leak" respiration (Fig. 2A).

When mitochondrial function was quantified for the entire red muscle, oxidative phosphorylation activity did not differ among treatments except for LI-LQ sardines, which exhibited higher rates of ATP synthesis and corresponding phosphorylating respiration, and higher basal non-phosphorylating respiration than the other groups $(P<0.05$, Fig. $2 \mathrm{~B})$. 
However, as the slopes were similar between LI-LQ and the other groups (Slope LI-LQ: $3.17 \pm$ 0.19; Slope other groups: $2.96 \pm 0.18 ; P>0.05)$, red muscles of LI-LQ sardines needed to consume more oxygen to produce the same amount of ATP compared to the sardines from the other three groups (Fig. 2B).

\subsection{Basal respiration in relation to body condition}

The rate of basal non-phosphorylating respiration at the mitochondrial level was significantly related to Le Cren body condition (Fig. 3). The segmented regression analysis showed a significant increase in basal non-phosphorylating respiration rate with body condition, until a condition threshold of $1.07\left(\mathrm{R}^{2}=0.45 ; P<0.001\right)$ beyond which no significant relation was found $(P>0.05$, Fig. 3$)$.

\section{Discussion}

The results demonstrate clear links between sardine red muscle energetics and foraging modes, indicating effects of both food size and ration. Reducing the size and/or quantity of food led to a series of mitochondrial energy sparing mechanisms (decrease in maximum oxygen consumption and ATP production, enhanced ATP production efficiency and reduced waste of oxygen linked to proton leak), presumably to maintain energy homeostasis. Such energy saving processes suggest that sardines feeding on small food items or small food quantities faced an energetic challenge. These metabolic processes were linked across different levels, from macroscopic integrative traits such as body mass and body condition to intracellular mechanisms such as mitochondrial efficiency. The effects of food ration were stronger at the whole animal level than at the tissue or mitochondrial level, whereas food size also induced marked mitochondrial adjustments beyond the effects at tissue or whole animal scale (Fig. 4). This shows that energy saving processes were not adequate to counteract detrimental effects of 
foraging on small particles. Indeed, despite an enhanced mitochondrial efficiency to produce ATP, SI sardines still exhibited lower body condition, body mass and growth performance, regardless of the ration provided (Queiros et al., 2019). Our results therefore support the hypothesis that filter-feeding behaviour is more costly than particulate-feeding in Mediterranean sardines (Queiros et al., 2019), unlike in other small pelagic species (Gibson \& Ezzi, 1992; Sanderson \& Cech, 1992; Van Der Lingen, 1995), and that this induces plastic responses in cellular energetics.

\subsection{Food size induces subcellular bioenergetic adjustments.}

Why would the size of food items affect traits like body condition, body mass or growth performance? Part of the answer may reside in the most striking result of our study, which is that small food items triggered bioenergetic adjustments in sardine muscle mitochondria. The effects of food size overwhelmed any potential effect of quantity. Small food items may have induced an increased utilisation of lipids, as intramuscular lipids were $\sim 50 \%$ lower in SI-SQ compared to LI-LQ sardines. Moreover, a reduction in glutamate oxidation is a known proteinsparing mechanism, which suggests that protein catabolism may have been occurring. This, together, may explain why SI sardine exhibited lower red muscle mass both in absolute and relative terms.

Feeding on small food items was also associated with decreased oxidative capacity and reduced energy (ATP) outflow, from mitochondria up to whole muscle. This involved a severe loss of mitochondrial power, i.e. a 50\% decrease in both maximal rates of ATP synthesis and oxygen consumption. These reduced maximal rates were balanced by a higher coupling efficiency; mitochondria of SI sardines consumed less oxygen than LI sardines to produce a given amount of ATP. The lower maximal respiratory capacity of skeletal muscle and economic management of cellular resources are energy saving mechanisms, decreasing the quantity of 
substrates required to produce ATP. Similar adjustments have been reported in skeletal muscle of birds at a critical stage of fasting, when endogenous lipid stores are depleted (Bourguignon et al., 2017; Monternier et al., 2017), and also in skeletal muscle of mammals fed on proteindeficient diets (Zangarelli et al., 2006). Overall, these results indicate that mitochondrial efficiency improves when energy balance is severely threatened in the sardine. Consequently, our results indicate that sardines were unable to cope with the high energy expenditure imposed by filter-feeding on small items, even when these were provided at high ration.

\subsection{Food quantity mainly influenced the whole organism.}

It is well established that food shortage triggers adaptive behavioural, physiological and cellular responses to lower costs of living, reducing metabolic rates, spontaneous activity and somatic growth (Metcalfe, Van Leeuwen, \& Killen, 2016). For example, the standard metabolic rate of juvenile brown trout Salmo trutta changes as a function of food availability, decreasing or increasing when fish are fed on a low or high ration, respectively (Auer et al., 2016), which was closely related to their growth rate (Auer et al., 2015). In our study, a 50\% reduction in ration negatively impacted body condition $(-26 \%)$, body mass $(-33 \%)$ and dramatically slowed growth rate of LI sardines (-64\%, similarly to what Queiros et al., 2019 found). While a similar trend was observed for growth rate in SI sardines when comparing between rations (-68\%) the difference was not significant, presumably because the energetic challenge of foraging on small items transcended any effect of ration (Table 1).

Energy conservation during food shortage is also enacted at a cellular level, by reductions in energy demanding processes and oxidative activity of metabolically active tissues, such as liver and skeletal muscles (McCue, 2010). For instance, the oxidative activity of brown trout muscle is positively correlated with food intake and maximum metabolic rate (Salin et al., 2016a; 2016b). In the sardines, bioenergetics of whole red muscle in the LI group was positively 
correlated with food availability, which is likely due to muscle mass. Because of lower body

442

443

444

445

mass and red muscle mass in food-restricted fish, maximal oxygen consumption and ATP synthesis rates of the muscle are depressed. Down regulation of aerobic metabolic pathways has been reported in the red muscle of food-restricted gilthead sea bream Sparus aurata (Bermejo-Nogales et al., 2011).

The lowered respiratory capacity of whole muscle in LI-SQ sardines appears mainly to be due to decreased mitochondrial content rather than to changes in mitochondrial activity or skeletal muscle protein content. Changes in mitochondrial content could be caused by dysregulation of autophagy and biogenesis. The former could be induced by caloric restriction (reviewed in Mehrabani et al., 2020) while the latter, which is extremely costly, is probably inhibited to conserve energy. It is also possible that the decrease in mitochondrial content and associated loss of metabolic power in the sardines is linked to decreased use of slow-twitch aerobic red muscle for a particulate capture feeding mode (Hood, 2009; Novak et al., 2005), as prey capture tends to use fast-twitch anaerobic white muscle (Bone, 1978).

\subsection{Body condition index and skeletal muscle mitochondria.}

The energetic constraints associated with the filtering mode led to very low body condition in the sardines. It is fascinating that, below a threshold value of 1.07 , declines in body condition index were strongly correlated with declines in basal non-phosphorylating respiration rate of muscle mitochondria. This threshold is surprisingly close to the mean body condition of sardines observed in the wild, around 1 (Brosset et al., 2015b), which may imply that wild populations are also at a threshold of bioenergetic disequilibrium. Basal non-phosphorylating respiration represents maximal proton leakage across the inner mitochondrial membrane. Limiting proton leak lowers costs of basal maintenance (Boutilier \& St-Pierre, 2002) but may carry an oxidative risk, such as an increased reactive oxygen species production (Salin et al., 
2018). A reduction of maintenance costs could also be achieved by decreasing mitochondrial content (Guderley, 2004), as observed in LI-SQ sardines (Fig 2b). That is, a decrease in mitochondrial content seems less harmful than directly reducing basal respiration rate itself, as LI-SQ body condition stayed closer to 1 than the SI groups.

Hence, the decline in mitochondrial energy wastage in sardines with poor condition suggests that modifying mitochondrial function provides an economical phenotype when metabolic costs of foraging are high compared to energy acquired.

\subsection{Conclusions}

Within our experimental conditions, we provide clear evidence that, in sardines, feeding on small prey can present a greater energetic challenge than reduced availability of large prey. Feeding sardines a restricted ration of large food items reduced their body condition, growth rate and body mass, revealing an unbalanced energy budget, but did not stimulate plastic metabolic responses within mitochondria. By contrast, feeding small items, whatever the quantity, induced energy-saving adjustments in mitochondria that are typical of a severe energetic challenge (Bourguignon et al., 2017; Costalago \& Palomera, 2014). The food size effect seems to be mediated by feeding mode in the sardines, with the switch from prey capture to filtering. Therefore, impacts of prey size on population condition could be profoundly nonlinear. Prey size might only have minor influence on condition as long as sardines use a capture feeding mode, but when prey species are small enough to trigger a change to filtering mode, there are dramatic consequences for body condition.

While this study focuses on sardines in the north-western Mediterranean Sea, it may be indicative of a widespread phenomenon linked to climate change. That is, if global warming causes systematic reductions in prey size (Daufresne et al., 2009), the extra time and energy required to forage could cause energy challenges at multiple levels of the food web. Coupled 
with increased metabolic demands of ectotherms in a warmer environment, this could lead to reduced growth rates and be a major contributor to declining final adult sizes in fishes (Gardner et al., 2011).

\section{References}

Atkinson, D. (1994). Temperature and Organism Size-A Law for Ectotherms? Advances in Ecological Research, 25, 1-58.

Audzijonyte, A., Richards, S. A., Stuart-Smith, R. D., Pecl, G., Edgar, G. J., Barrett, N. S., ... Blanchard, J. L. (2020). Fish body sizes change with temperature but not all species shrink with warming. Nature Ecology and Evolution, 4(6), 809-814. doi: $10.1038 / \mathrm{s} 41559-020-1171-0$

Auer, S. K., Salin, K., Rudolf, A. M., Anderson, G. J., \& Metcalfe, N. B. (2015). Flexibility in metabolic rate confers a growth advantage under changing food availability. Journal of Animal Ecology, 84(5), 1405-1411. doi: 10.1111/1365-2656.12384

Auer, S. K., Salin, K., Rudolf, A. M., Anderson, G. J., \& Metcalfe, N. B. (2016). Differential effects of food availability on minimum and maximum rates of metabolism. Biology Letters, 12(10), 0-4. doi: 10.1098/rsbl.2016.0586

Beavis, A. D., \& Lehninger, A. L. (1986). The upper and lower limits of the mechanistic stoichiometry of mitochondrial oxidative phosphorylation: Stoichiometry of oxidative phosphorylation. European Journal of Biochemistry, 158(2), 315-322. doi: 10.1111/j.1432-1033.1986.tb09753.x

Bermejo-Nogales, A., Benedito-Palos, L., Calduch-Giner, J. A., \& Pérez-Sánchez, J. (2011). Feed restriction up-regulates uncoupling protein 3 (UCP3) gene expression in heart and red muscle tissues of gilthead sea bream (Sparus aurata L.). New insights in substrate oxidation and energy expenditure. Comparative Biochemistry and Physiology - A Molecular and Integrative Physiology, 159(3), 296-302. doi: 10.1016/j.cbpa.2011.03.024

Boël, M., Romestaing, C., Voituron, Y., \& Roussel, D. (2019). Allometry of mitochondrial efficiency is set by metabolic intensity. Proceedings of the Royal Society B: Biological Sciences, 286(1911). doi: 10.1098/rspb.2019.1693

Bone, Q. (1978). Locomotor Muscle (Vol. 7). Academic Press. doi: 10.1007/BF00007710

Bopp, L., Resplandy, L., Orr, J. C., Doney, S. C., Dunne, J. P., Gehlen, M., ... Vichi, M. (2013). Multiple stressors of ocean ecosystems in the 21st century: Projections with CMIP5 models. Biogeosciences, 10(10), 6225-6245. doi: 10.5194/bg-10-6225-2013

Bourguignon, A., Rameau, A., Toullec, G., Romestaing, C., \& Roussel, D. (2017). Increased mitochondrial energy efficiency in skeletal muscle after long-term fasting: Its relevance to animal performance. Journal of Experimental Biology, 220(13), 2445-2451. doi: 10.1242/jeb.159087

Boutilier, R. G., \& St-Pierre, J. (2002). Adaptive plasticity of skeletal muscle energetics in 

hibernating frogs: Mitochondrial proton leak during metabolic depression. Journal of Experimental Biology, 205(15), 2287-2296.

Brand, M. (2005). The efficiency and plasticity of mitochondrial energy transduction. Biochemical Society Transactions, 33(5), 897-904. doi: 10.1042/BST20050897

Brand, M. D. (2000). Uncoupling to survive? The role of mitochondrial inefficiency in ageing. Experimental Gerontology, 35(6), 811-820. doi: https://doi.org/10.1016/S05315565(00)00135-2

Brosset, P., Fromentin, J. M., Ménard, F., Pernet, F., Bourdeix, J. H., Bigot, J. L., ... Saraux, C. (2015a). Measurement and analysis of small pelagic fish condition: A suitable method for rapid evaluation in the field. Journal of Experimental Marine Biology and Ecology, 462, 90-97. doi: 10.1016/j.jembe.2014.10.016

Brosset, P., Fromentin, J. M., Van Beveren, E., Lloret, J., Marques, V., Basilone, G., ... Saraux, C. (2017). Spatio-temporal patterns and environmental controls of small pelagic fish body condition from contrasted Mediterranean areas. Progress in Oceanography, 151, 149-162. doi: 10.1016/j.pocean.2016.12.002

Brosset, P., Le Bourg, B., Costalago, D., BǍnaru, D., Van Beveren, E., Bourdeix, J. H., ... Saraux, C. (2016a). Linking small pelagic dietary shifts with ecosystem changes in the Gulf of Lions. Marine Ecology Progress Series, 554, 157-171. doi: 10.3354/meps 11796

Brosset, P., Lloret, J., Muñoz, M., Fauvel, C., Van Beveren, E., Marques, V., ... Saraux, C. (2016b). Body reserves mediate trade-offs between life-history traits: New insights from small pelagic fish reproduction. Royal Society Open Science, 3(10). doi: 10.1098/rsos. 160202

Brosset, P., Ménard, F., Fromentin, J. M., Bonhommeau, S., Ulses, C., Bourdeix, J. H., ... Saraux, C. (2015b). Influence of environmental variability and age on the body condition of small pelagic fish in the Gulf of Lions. Marine Ecology Progress Series, 529, 219231. doi: $10.3354 /$ meps 11275

Colinet, H., Renault, D., \& Roussel, D. (2017). Cold acclimation allows Drosophila flies to maintain mitochondrial functioning under cold stress. Insect Biochemistry and Molecular Biology, 80, 52-60. doi: 10.1016/j.ibmb.2016.11.007

Conley, K. E., Jubrias, S. A., Cress, M. E., \& Esselman, P. (2013). Exercise efficiency is reduced by mitochondrial uncoupling in the elderly. Experimental Physiology, 98(3), 768-777. doi: 10.1113/expphysiol.2012.067314

Conover, D. O., \& Munch, S. B. (2002). Sustaining fisheries yields over evolutionary time scales. Science, 297(5578), 94-96. doi: 10.1126/science.1074085

Costalago, D., Garrido, S., \& Palomera, I. (2015). Comparison of the feeding apparatus and diet of European sardines Sardina pilchardus of Atlantic and Mediterranean waters: Ecological implications. Journal of Fish Biology, 86(4), 1348-1362. doi: $10.1111 /$ jfb. 12645

Costalago, D., \& Palomera, I. (2014). Feeding of European pilchard (Sardina pilchardus) in the northwestern Mediterranean: from late larvae to adults. Scientia Marina, 78(1), 4154. doi: 10.3989/scimar.03898.06d

Crowder, L. B. (1985). Optimal foraging and feeding mode shifts in fishes. Environmental Biology of Fishes, 12(1), 57-62. doi: 10.1007/BF00007710 
Daufresne, M., Lengfellner, K., \& Sommer, U. (2009). Global warming benefits the small in aquatic ecosystems. Proceedings of the National Academy of Sciences of the United States of America, 106(31), 12788-12793. doi: 10.1073/pnas.0902080106

Distefano, G., Standley, R. A., Zhang, X., Carnero, E. A., Yi, F., Cornnell, H. H., \& Coen, P. M. (2018). Physical activity unveils the relationship between mitochondrial energetics, muscle quality, and physical function in older adults. Journal of Cachexia, Sarcopenia and Muscle, 9(2), 279-294. doi: 10.1002/jcsm.12272

Fontaine, E. M., Moussa, M., Devin, A., Garcia, J., Ghisolfi, J., Rigoulet, M., \& Leverve, X. M. (1996). Effect of polyunsaturated fatty acids deficiency on oxidative phosphorylation in rat liver mitochondria. Biochimica et Biophysica Acta - Bioenergetics, 1276(3), 181187. doi: 10.1016/0005-2728(96)00075-8

Forster, J., Hirst, A. G., \& Atkinson, D. (2012). Warming-induced reductions in body size are greater in aquatic than terrestrial species. Proceedings of the National Academy of Sciences of the United States of America, 109(47), 19310-19314. doi: 10.1073/pnas.1210460109

Gardner, J. L., Peters, A., Kearney, M. R., Joseph, L., \& Heinsohn, R. (2011). Declining body size: A third universal response to warming? Trends in Ecology and Evolution, 26(6), 285-291. doi: 10.1016/j.tree.2011.03.005

Garrido, S., Marçalo, A., Zwolinski, J., \& Van Der Lingen, C. D. (2007). Laboratory investigations on the effect of prey size and concentration on the feeding behaviour of Sardina pilchardus. Marine Ecology Progress Series, 330, 189-199. doi: 10.3354/meps330189

Garzke, J., Ismar, S. M. H., \& Sommer, U. (2015). Climate change affects low trophic level marine consumers: warming decreases copepod size and abundance. Oecologia, 177(3), 849-860. doi: 10.1007/s00442-014-3130-4

Gibson, R. N., \& Ezzi, I. A. (1992). The relative profitability of particulate- and filter-feeding in the herring, Clupea harengus L. Journal of Fish Biology, 40(4), 577-590. doi: 10.1111/j.1095-8649.1992.tb02607.x

Gornall, A. G., Bardawill, C. J., \& David, M. M. (1949). Determination of serum proteins by means of the biuret reaction. The Journal of Biological Chemistry, 177(2), 751-766.

Guderley, H. (2004). Metabolic responses to low temperature in fish muscle. Biological Reviews of the Cambridge Philosophical Society, 79(2), 409-427. doi: 10.1017/S1464793103006328

Halpern, B. S., Walbridge, S., Selkoe, K. A., Kappel, C. V., Micheli, F., D’Agrosa, C., ... Watson, R. (2008). A Global Map of Human Impact on cadherin-mediated cell adhesion in metazoans may reflect the co-option of a class of proteins whose earliest function was to interpret and re- Marine Ecosystems. Science, 319(February), 948-953.

Hood, D. A. (2009). Mechanisms of exercise-induced mitochondrial biogenesis in skeletal muscle. Applied Physiology, Nutrition and Metabolism, 34(3), 465-472. doi: 10.1139/H09-045

Jørgensen, C., Enberg, K., Dunlop, E. S., Arlinghaus, R., Boukal, D. S., Brander, K., ... Rijnsdorp, A. D. (2007). Ecology: Managing evolving fish stocks. Science, 318(5854), 1247-1248. doi: 10.1126/science. 1148089 
Koch, R. E., Buchanan, K. L., Casagrande, S., Crino, O., Dowling, D. K., Hill, G. E., ... Stier, A. (2021). Integrating Mitochondrial Aerobic Metabolism into Ecology and Evolution. Trends in Ecology and Evolution, 1-12. doi: 10.1016/j.tree.2020.12.006

Le Bourg, B., Bănaru, D., Saraux, C., Nowaczyk, A., Le Luherne, E., Jadaud, A., ... Richard, P. (2015). Trophic niche overlap of sprat and commercial small pelagic teleosts in the Gulf of Lions (NW Mediterranean Sea). Journal of Sea Research, 103(September), 138146. doi: 10.1016/j.seares.2015.06.011

Lee, S., Lee, Y. M., Kim, K. H., Kim, H. C., Park, C. J., Park, J. W., ... Hwang, H. K. (2018). Effects of food availability on growth performance and immune-related gene expression of juvenile olive flounder (Paralichthys olivaceus). Fish and Shellfish Immunology, 80(May), 348-356. doi: 10.1016/j.fsi.2018.06.021

McCue, M. D. (2010). Starvation physiology: Reviewing the different strategies animals use to survive a common challenge. Comparative Biochemistry and Physiology - A Molecular and Integrative Physiology, 156(1), 1-18. doi: 10.1016/j.cbpa.2010.01.002

Mehrabani, S., Bagherniya, M., Askari, G., Read, M. I., \& Sahebkar, A. (2020). The effect of fasting or calorie restriction on mitophagy induction: a literature review. Journal of Cachexia, Sarcopenia and Muscle, 11(6), 1447-1458. doi: 10.1002/jcsm.12611

Metcalfe, N. B., Van Leeuwen, T. E., \& Killen, S. S. (2016). Does individual variation in metabolic phenotype predict fish behaviour and performance? Journal of Fish Biology, 88(1), 298-321. doi: 10.1111/jfb.12699

Monternier, P. A., Teulier, L., Drai, J., Bourguignon, A., Collin-Chavagnac, D., Hervant, F., ... Roussel, D. (2017). Mitochondrial oxidative phosphorylation efficiency is upregulated during fasting in two major oxidative tissues of ducklings. Comparative Biochemistry and Physiology -Part A : Molecular and Integrative Physiology, 212(May), 1-8. doi: 10.1016/j.cbpa.2017.06.018

Morrongiello, J. R., Sweetman, P. C., \& Thresher, R. E. (2019). Fishing constrains phenotypic responses of marine fish to climate variability. Journal of Animal Ecology, 88(11), 1645-1656. doi: 10.1111/1365-2656.12999

Nedergaard, J., \& Cannon, B. (2018). Brown adipose tissue as a heat-producing thermoeffector. In Handbook of Clinical Neurology (1st ed., Vol. 156). Elsevier B.V. doi: 10.1016/B978-0-444-63912-7.00009-6

Nogueira, V., Walter, L., Avéret, N., Fontaine, E., Rigoulet, M., \& Leverve, X. M. (2002). Thyroid status is a key regulator of both flux and efficiency of oxidative phosphorylation in rat hepatocytes. Journal of Bioenergetics and Biomembranes, 34(1), 55-66. doi: 10.1023/A:1013822820840

Novak, C. M., Jiang, X., Wang, C., Teske, J. A., Kotz, C. M., \& Levine, J. A. (2005). Caloric restriction and physical activity in zebrafish (Danio rerio). Neuroscience Letters, 383(12), 99-104. doi: 10.1016/j.neulet.2005.03.048

Palomera, I., Olivar, M. P., Salat, J., Sabatés, A., Coll, M., García, A., \& Morales-Nin, B. (2007). Small pelagic fish in the NW Mediterranean Sea: An ecological review. Progress in Oceanography, 74(2-3), 377-396. doi: 10.1016/j.pocean.2007.04.012

Queiros, Q., Fromentin, J. M., Gasset, E., Dutto, G., Huiban, C., Metral, L., ... Saraux, C. (2019). Food in the sea: Size also matters for pelagic fish. Frontiers in Marine Science, 

6(JUL), 1-13. doi: 10.3389/fmars.2019.00385

Rolfe, D. F. S., \& Brand, M. D. (1997). The physiological significance of mitochondrial proton leak in animal cells and tissues. Bioscience Reports, 17(1), 9-16. doi: 10.1023/A:1027327015957

Roussel, D., Salin, K., Dumet, A., Romestaing, C., Rey, B., \& Voituron, Y. (2015). Oxidative phosphorylation efficiency, proton conductance and reactive oxygen species production of liver mitochondria correlates with body mass in frogs. Journal of Experimental Biology, 218(20), 3222-3228. doi: 10.1242/jeb.126086

Roussel, D., \& Voituron, Y. (2020). Mitochondrial Costs of Being Hot: Effects of Acute Thermal Change on Liver Bioenergetics in Toads (Bufo bufo). Frontiers in Physiology, 11(March), 1-10. doi: 10.3389/fphys.2020.00153

Rumolo, P., Bonanno, A., Barra, M., Fanelli, E., Calabrò, M., Genovese, S., ... Basilone, G. (2016). Spatial variations in feeding habits and trophic levels of two small pelagic fish species in the central Mediterranean Sea. Marine Environmental Research, 115, 65-77. doi: 10.1016/j.marenvres.2016.02.004

Salin, K., Auer, S. K., Anderson, G. J., Selman, C., \& Metcalfe, N. B. (2016a). Inadequate food intake at high temperatures is related to depressed mitochondrial respiratory capacity. Journal of Experimental Biology, 219(9), 1356-1362. doi: 10.1242/jeb.133025

Salin, K., Auer, S. K., Rey, B., Selman, C., \& Metcalfe, N. B. (2015). Variation in the link between oxygen consumption and ATP production, and its relevance for animal performance. Proceedings of the Royal Society B: Biological Sciences, 282(1812). doi: 10.1098/rspb.2015.1028

Salin, K., Auer, S. K., Rudolf, A. M., Anderson, G. J., Selman, C., \& Metcalfe, N. B. (2016b). Variation in metabolic rate among individuals is related to tissue-specific differences in mitochondrial leak respiration. Physiological and Biochemical Zoology, 89(6), 511-523. doi: 10.1086/688769

Salin, K., Roussel, D., Rey, B., \& Voituron, Y. (2012). David and Goliath: A Mitochondrial Coupling Problem? Journal of Experimental Zoology Part A: Ecological Genetics and Physiology, 317(5), 283-293. doi: 10.1002/jez.1722

Salin, K., Villasevil, E. M., Anderson, G. J., Auer, S. K., Selman, C., Hartley, R. C., ... Metcalfe, N. B. (2018). Decreased mitochondrial metabolic requirements in fasting animals carry an oxidative cost. Functional Ecology, 32(9), 2149-2157. doi: $10.1111 / 1365-2435.13125$

Salin, K., Villasevil, E. M., Anderson, G. J., Lamarre, S. G., Melanson, C. A., McCarthy, I., ... Metcalfe, N. B. (2019). Differences in mitochondrial efficiency explain individual variation in growth performance. Proceedings of the Royal Society B: Biological Sciences, 286(1909). doi: 10.1098/rspb.2019.1466

Sanderson, S. L., \& Cech, J. J. (1992). Energetic Cost of Suspension Feeding versus Particulate Feeding by Juvenile Sacramento Blackfish. Transactions of the American Fisheries Society, 121(2), 149-157. doi: 10.1577/15488659(1992) $121<0149:$ ecosfv>2.3.co;2

Saraux, C., Van Beveren, E., Brosset, P., Queiros, Q., Bourdeix, J. H., Dutto, G., ... Fromentin, J. M. (2019). Small pelagic fish dynamics: A review of mechanisms in the 
Gulf of Lions. Deep-Sea Research Part II: Topical Studies in Oceanography, 159(xxxx), 52-61. doi: 10.1016/j.dsr2.2018.02.010

Sibert, J., Hampton, J., Kleiber, P., \& Maunder, M. (2006). Biomass, Size, and Trophic Status of Top Predators in the Pacific Ocean. Science, 314(March), 1773-1777. doi: 10.1126/science. 1135347

Sommer, U., Paul, C., \& Moustaka-Gouni, M. (2015). Warming and ocean acidification effects on phytoplankton - From species shifts to size shifts within species in a mesocosm experiment. PLoS ONE, 10(5), 1-17. doi: 10.1371/journal.pone.0125239

Sun, L., \& Chen, H. (2009). Effects of ration and temperature on growth, fecal production, nitrogenous excretion and energy budget of juvenile cobia (Rachycentron canadum). Aquaculture, 292(3-4), 197-206. doi: 10.1016/j.aquaculture.2009.04.041

Teulier, L., Rouanet, J. L., Letexier, D., Romestaing, C., Belouze, M., Rey, B., ... Roussel, D. (2010). Cold-acclimation-induced non-shivering thermogenesis in birds is associated with upregulation of avian UCP but not with innate uncoupling or altered ATP efficiency. Journal of Experimental Biology, 213(14), 2476-2482. doi: 10.1242/jeb.043489

Teulier, L., Thoral, E., Queiros, Q., McKenzie, D. J., Roussel, D., Dutto, G., ... Saraux, C. (2019). Muscle bioenergetics of two emblematic Mediterranean fish species: Sardina pilchardus and Sparus aurata. Comparative Biochemistry and Physiology-Part A : Molecular and Integrative Physiology, 235(June), 174-179. doi: 10.1016/j.cbpa.2019.06.008

Thoral, E., Queiros, Q., Roussel, D., Dutto, G., Gasset, E., McKenzie, D. J., ...Teulier, L. (2021a). Changes in foraging mode caused by a decline in prey size have major bioenergetic consequences for a small pelagic fish, Dryad, Dataset, https://doi.org/10.5061/dryad.xpnvx0kfp

Thoral, E., Roussel, D., Chinopoulos, C., Teulier, L., \& Salin, K. (2021b). Low oxygen levels can help to prevent the detrimental effect of acute warming on mitochondrial efficiency in fish. Biology Letters, 17.

Toyomizu, M., Kikusato, M., Kawabata, Y., Azad, M. A. K., Inui, E., \& Amo, T. (2011). Meat-type chickens have a higher efficiency of mitochondrial oxidative phosphorylation than laying-type chickens. Comparative Biochemistry and Physiology - A Molecular and Integrative Physiology, 159(1), 75-81. doi: 10.1016/j.cbpa.2011.01.020

Van Beveren, E., Bonhommeau, S., Fromentin, J. M., Bigot, J. L., Bourdeix, J. H., Brosset, P., ... Saraux, C. (2014). Rapid changes in growth, condition, size and age of small pelagic fish in the Mediterranean. Marine Biology, 161(8), 1809-1822. doi: 10.1007/s00227-014-2463-1

Van Der Lingen, C. D. (1995). Respiration rate of adult pilchard Sardinops sagax in relation to temperature, voluntary swimming speed and feeding behaviour. Marine Ecology Progress Series, 129(1-3), 41-54. doi: 10.3354/meps129041

Webb, P. W. (1998). Entrainment by river chub Nocomis micropogon and smallmouth bass Micropterus dolomieu on cylinders. Journal of Experimental Biology, 201(16), 24032412.

Zangarelli, A., Chanseaume, E., Morio, B., Brugère, C., Mosoni, L., Rousset, P., ... Walrand, 
S. (2006). Synergistic effects of caloric restriction with maintained protein intake on skeletal muscle performance in 21-month-old rats: a mitochondria-mediated pathway. The FASEB Journal, 20(14), 2439-2450. doi: 10.1096/fj.05-4544com

748 Zarubin, M., Farstey, V., Wold, A., Falk-Petersen, S., \& Genin, A. (2014). Intraspecific differences in lipid content of calanoid copepods across fine-scale depth ranges within the photic layer. PLoS ONE, 9(3), 1-10. doi: 10.1371/journal.pone.0092935 
753 Figure 1. Illustration of the integrative levels of the red muscle bioenergetics in sardine, 754 from isolated mitochondria, to the whole tissue.

755 Substrates are oxidized by the complexes of the electron transport system (ETS) and ATP is 756 produced through a phosphorylation process by the ATP synthase. The ETS and ATP synthase 757 are enclosed in the inner membrane of the mitochondria (panel A). Mitochondrial respiration 758 rates associated to either basal non-phosphorylating state (BASAL) and/or phosphorylating state (PHOSPHO) were assessed at different levels of integration. 1) Mitochondrial oxygen consumption was coupled to the amount of ATP produced, to obtain the mitochondrial efficiency which is the slope of the linear regression between oxygen consumption and ATP production, called $\mathrm{P} / \mathrm{O}$ ratio (panel B). 2) The muscle fibre respiration rates were induced by addition of different substrates to discriminate the metabolic pathways fuelling the red muscle (panel C). 3) The whole red muscle oxidation phosphorylation activity was calculated to estimate the relative importance of the whole muscle bioenergetics. The red muscle is positioned along the lateral line and is clearly separated from the white muscle (panel D). ETS: Electron transport system; ATP: Adenosine triphosphate; ADP: adenosine diphosphate; Pi: Phosphate inorganic; IMS: intermembrane space of the mitochondrion; M: matrix of the mitochondrion. See the "Material and Methods" section for further details.

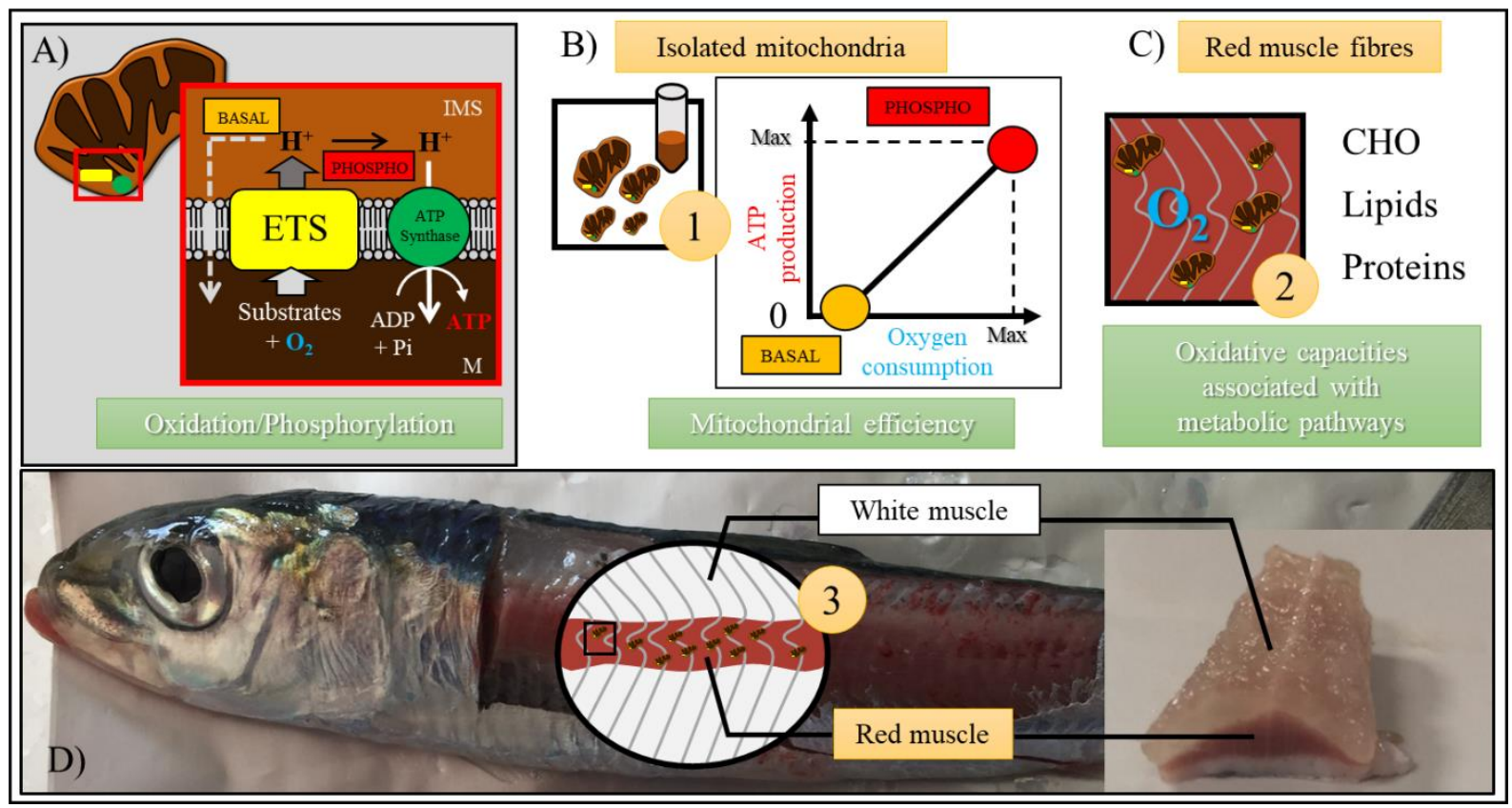


770 Figure 2. Mitochondrial efficiency of sardine that received different quantities and sizes

771 of food items, at the mitochondrial level (Panel A; LI-LQ: large food items in large quantities,

$772 \mathrm{n}=11$; LI-SQ: large food items in small quantities, $\mathrm{n}=12$; SI-LQ: small food items in large 773 quantities, $n=11$; SI-SQ: small food items in small quantities, $n=9$ ) and red muscle level 774 (Panel B, LI-LQ: $\mathrm{n}=11$, LI-SQ: $\mathrm{n}=11$; SI-LQ: $\mathrm{n}=10$; SI-SQ: $\mathrm{n}=9$ ). In panel A, the two trend 775 curves drawn are those of the "large food items" (LI: $y=3.03 x-44.40)$ and "small food items 776 (SI: $y=3.19 x-37.96)$ groups, and in panel $\mathrm{B}$, the trend curves are those of LI-LQ group $(\mathrm{y}=$ $7773.17 \mathrm{x}-4.52)$ and of the other groups together $(\mathrm{y}=2.97 \mathrm{x}-1.77)$. These data were analysed 778 using a linear-mixed effects model with size and quantity of items as fixed-effects and sex as 779 random effect. The values shown are means \pm s.e.m. (the error bars of the basal oxygen 780 consumption are small enough that they are hidden by the points, see zoom boxes). An asterisk 781 represents a significantly difference in maximal oxygen consumption, ATP production and 782 basal oxygen consumption (see zoom boxes) between diets composed of different size food 783 items (Panel A, difference between LI and SI) and between LI-LQ sardines and other groups $784 \quad($ Panel $\mathrm{B} ; * P<0.05 ; * * P<0.01)$. 


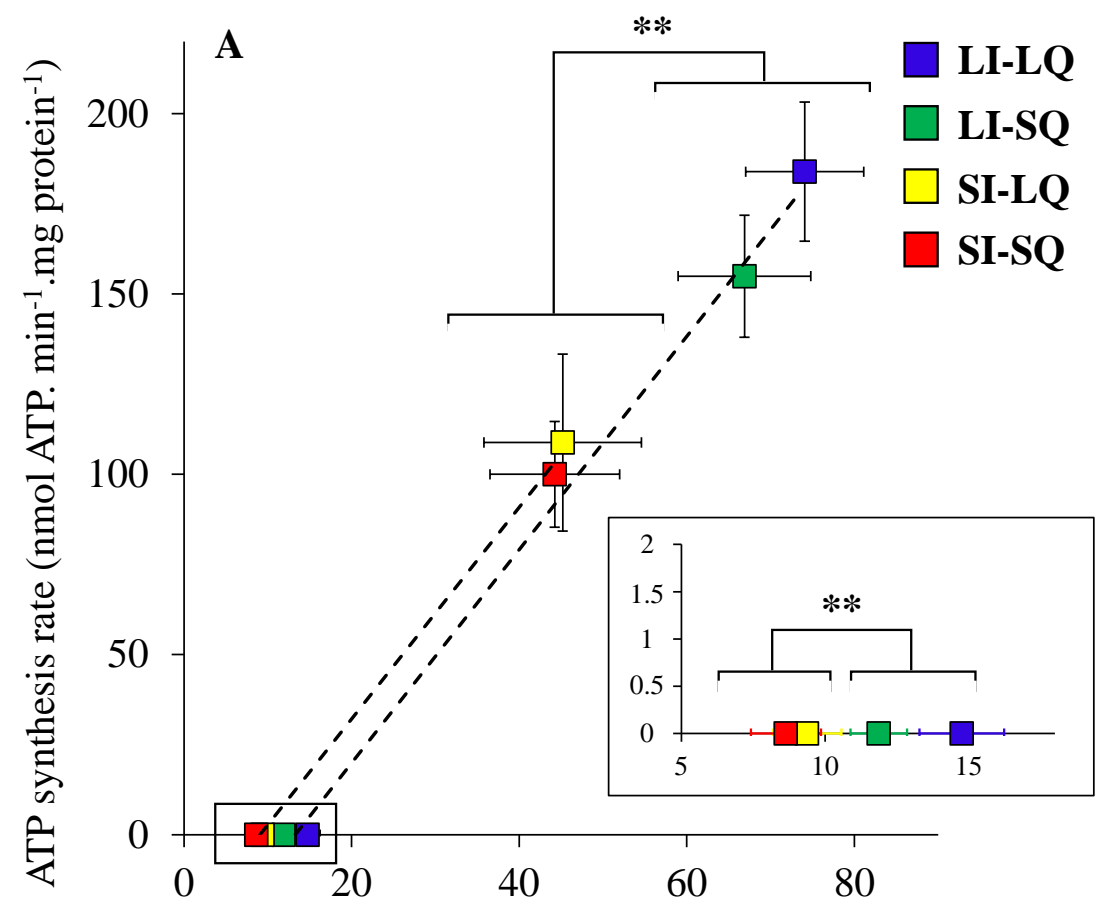

Oxygen consumption rate (nmol O. min $^{-1}$. mg protein ${ }^{-1}$ )

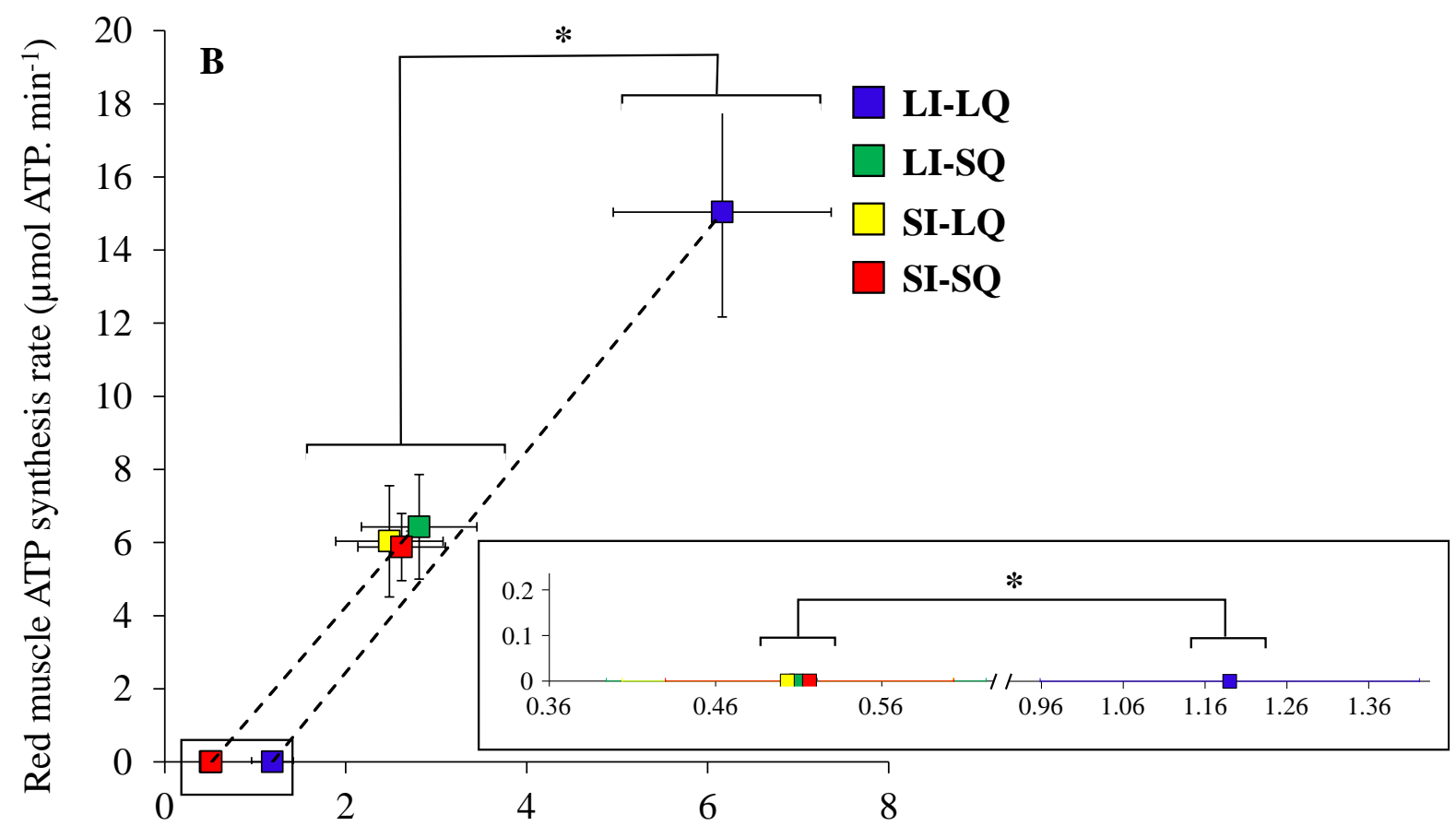

Red muscle oxygen consumption rate $\left(\mu \mathrm{mol} \mathrm{O} \cdot \mathrm{min}^{-1}\right)$ 
Figure 3. Basal oxygen consumption at the mitochondrial level as a function of sardine body condition index. Fish of each treatment are represented by a coloured circle. Sardines fed with large food items are represented in blue for large quantity $(\mathrm{LI}-\mathrm{LQ}$, $\mathrm{n}=11)$ and in green for small quantity $(\mathrm{LI}-\mathrm{SQ}, \mathrm{n}=12)$. Yellow and red circles represent sardines fed with small food items, in large $(\mathrm{SI}-\mathrm{LQ}, \mathrm{n}=10)$ and small $(\mathrm{SI}-\mathrm{SQ}, \mathrm{n}=11)$ quantities, respectively. Basal mitochondrial respiration in nmol O. $\mathrm{min}^{-1} \cdot \mathrm{mg}$ protein ${ }^{-1}$ is positively correlated to the body condition index when the BCI is less than $1.07(P<0.001)$. Above this threshold, there is no longer a regression between these two parameters.

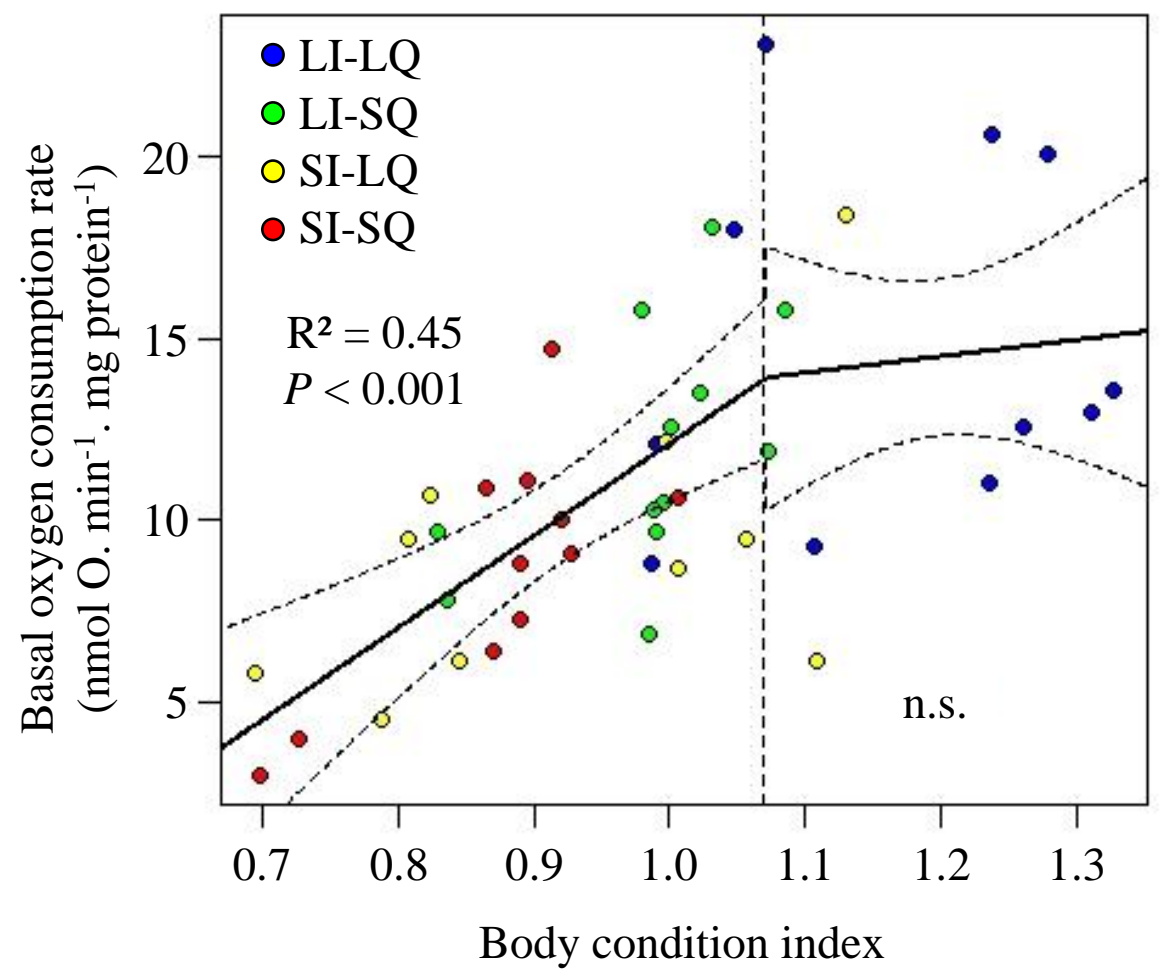

807 
Figure 4. Whole-organism, muscle, and subcellular consequences of the quantity and/or size of food. In order to investigate the effect of size and/or quantity of food, a fully factorial protocol has been set up. Size and quantity impacted the whole-organism and muscle parameters, whereas subcellular bioenergetics have been modified only by size of food items. Significant effects are illustrated by an asterisk. As foraging mode depends on food size (Costalago et al., 2015; Garrido et al., 2007), the effect described by size is called "foraging mode" (FM). Lowering the quantity of food by 50\% induces a severe "caloric restriction" (CR). [1] Queiros et al., 2019

\begin{tabular}{|c|c|c|c|c|c|c|c|c|c|}
\hline \multirow{3}{*}{\multicolumn{2}{|c|}{$\begin{array}{l}\text { Whole } \\
\text { organism } \\
\text { \& Muscle }\end{array}$}} & \multicolumn{3}{|c|}{$[1$, present study $]$} & \multicolumn{5}{|c|}{ [present study] } \\
\hline & & \multicolumn{2}{|c|}{ Food size } & \multirow{2}{*}{ Effect } & \multirow{2}{*}{\multicolumn{2}{|c|}{$\begin{array}{l}\text { Sub } \\
\text { cellular } \\
\text { level }\end{array}$}} & \multicolumn{2}{|c|}{ Food size } & \multirow{2}{*}{ Effect } \\
\hline & & Large & Small & & & & Large & Small & \\
\hline \multirow{5}{*}{ 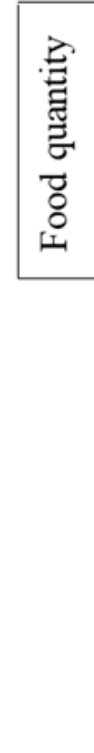 } & Large & 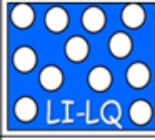 & 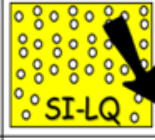 & $\underset{\text { mode }}{\text { Foraging }}{ }^{*}$ & \multirow{2}{*}{ 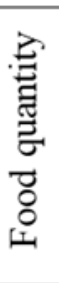 } & Large & $\begin{array}{l}\text { OOOO } \\
\text { OOO } \\
\text { OLI-LQO } \\
\text { OLI-LQ }\end{array}$ & 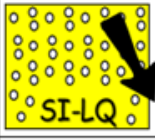 & $\begin{array}{c}\text { Foraging } \\
\text { mode }\end{array}$ \\
\hline & Small & $\mid \begin{array}{cc}0 & 0 \\
0 & 0 \\
\text { LI-SQ }\end{array}$ & & $\begin{array}{c}\text { Foraging } \\
\text { mode }\end{array}$ & & Small & \begin{tabular}{|ll}
$O$ & 0 \\
$O$ & $O$ \\
LI-SQ
\end{tabular} & & $\begin{array}{c}\text { Foraging } \\
\text { mode }\end{array}$ \\
\hline & Effect & $\begin{array}{r}\text { Caloric* } \\
\text { Restriction }\end{array}$ & $\begin{array}{r}\text { Caloric* } \\
\text { Restriction }\end{array}$ & FM $\times C^{*}$ & & Effect & $\begin{array}{c}\text { Caloric } \\
\text { Restriction }\end{array}$ & $\begin{array}{c}\text { Caloric } \\
\text { Restriction }\end{array}$ & FM $\times \mathrm{CR}^{*}$ \\
\hline & - & \multicolumn{3}{|c|}{$\begin{array}{l}\text { Body mass gain } \\
\text { Growth rate } \\
\text { Body condition }\end{array}$} & & - & \multicolumn{3}{|c|}{$\begin{array}{l}\text { Fluxes }\left(\mathrm{O}_{2}, \mathrm{ATP}\right) \\
\text { Protein catabolism } \\
\text { Efficiency }\end{array}$} \\
\hline & \multicolumn{9}{|c|}{ Unbalanced energy budget } \\
\hline
\end{tabular}




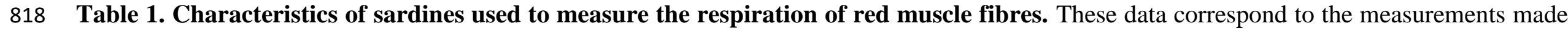
on the day sardines were euthanised. Values are mean \pm s.e.m. N corresponds to the number of individuals randomly split into 4 treatments, sorted in three sex categories (male, female and indeterminate). Cumulative growth represents the total length gain in mm, over the entire experiment. $\mathrm{RM} / \mathrm{BM}$ ratio corresponds to the relative red muscle mass, which is the proportion of the red muscle mass over the body mass. Data were analysed with a linear mixed-effect model with size and quantity as fixed-effects and sex as random effect. Data with different superscripts are significantly different at $\mathrm{P}<0.05$. The boxes with the asterisks indicated a global effect of item size $(* * \mathrm{P}<0.001)$. 


\begin{tabular}{|c|c|c|c|c|c|c|}
\hline $\begin{array}{r}\mathrm{N} \\
(\mathrm{M} / \mathrm{F} / \text { indeterminate })\end{array}$ & $\begin{array}{c}8-11 \\
(6 / 3 / 2)\end{array}$ & $\begin{array}{l}10-12 \\
(5 / 6 / 1)\end{array}$ & $\begin{array}{c}9-11 \\
(3 / 5 / 2)\end{array}$ & $\begin{array}{l}10-12 \\
(3 / 8 / 1)\end{array}$ & & \\
\hline Final BCI & $1.17 \pm 0.04^{\mathrm{a}}$ & $0.98 \pm 0.02^{\mathrm{b}}$ & $0.93 \pm 0.05^{b}$ & $0.87 \pm 0.02^{b}$ & $\begin{array}{l}\text { Size: } P<0.001 \\
\text { Quantity: } P=0.001 \\
\text { Size*Quantity: } P=0 .\end{array}$ & $\begin{array}{l}824 \\
825 \\
61 \\
826\end{array}$ \\
\hline Fat content $(\%)$ & $13.46 \pm 1.40^{\mathrm{a}}$ & $8.86 \pm 0.76^{\mathrm{b}}$ & $8.12 \pm 0.81^{b}$ & $6.93 \pm 0.37^{\mathrm{b}}$ & $\begin{array}{l}\text { Size: } \boldsymbol{P}<\mathbf{0 . 0 0 1} \\
\text { Quantity: } \boldsymbol{P}=\mathbf{0 . 0 0 2} \\
\text { Size*Quantity: } P=0 .\end{array}$ & $\begin{array}{c}820 \\
827 \\
828 \\
55 \\
829\end{array}$ \\
\hline Cumulative growth (mm) & $14.29 \pm 1.68^{\mathrm{a}}$ & $5.05 \pm 1.07^{\mathrm{b}}$ & $5.27 \pm 1.42^{\mathrm{b}}$ & $1.64 \pm 0.46^{\mathrm{b}}$ & $\begin{array}{l}\text { Size: } P<0.001 \\
\text { Quantity: } P<0.001 \\
\text { Size*Quantity: } P=0 .\end{array}$ & $\begin{array}{r}830 \\
831 \\
\mathbf{0 2 5} \\
832\end{array}$ \\
\hline Relative growth (\%) & $12.55 \pm 1.56^{\mathrm{a}}$ & $4.35 \pm 0.91^{\mathrm{b}}$ & $4.60 \pm 1.29^{b}$ & $1.34 \pm 0.36^{\mathrm{b}}$ & $\begin{array}{l}\text { Size: } \mathrm{P}<0.001 \\
\text { Quantity: } \mathrm{P}<0.001 \\
\text { Size*Quantity: } \mathrm{P}=\mathbf{0}\end{array}$ & $\begin{array}{r}832 \\
833 \\
834 \\
\mathbf{0 2 9} \\
835\end{array}$ \\
\hline Body mass (g) & $19.23 \pm 1.38^{\mathrm{a}}$ & $13.98 \pm 0.62^{b}$ & $14.22 \pm 1.19^{b}$ & $12.81 \pm 0.73^{b}$ & $\begin{array}{l}\text { Size: } \boldsymbol{P}=\mathbf{0 . 0 0 5} \\
\text { Quantity: } \boldsymbol{P}=\mathbf{0 . 0 0 1} \\
\text { Size*Quantity: } P=0 .\end{array}$ & $\begin{array}{c}835 \\
836 \\
837 \\
58 \\
838\end{array}$ \\
\hline Red muscle mass (g) & $1.59 \pm 0.17^{\mathrm{a}}$ & $1.18 \pm 0.06^{\mathrm{a}, \mathrm{b}}$ & $0.98 \pm 0.13^{\mathrm{b}}$ & $0.91 \pm 0.07^{\mathrm{b}}$ & $\begin{array}{l}\text { Size: } P<0.001 \\
\text { Quantity: } P=0.039\end{array}$ & $\begin{array}{l}839 \\
840\end{array}$ \\
\hline RM/BM (\%) & $8.11 \pm 0.39$ & $8.46 \pm 0.20$ & $6.70 \pm 0.45$ & $7.09 \pm 0.30$ & Size: $P<0.001$ & \\
\hline
\end{tabular}


Table 2. Maximal respiration ETS activity and mitochondrial content of sardine red muscle for each feeding treatment. The maximal respiration rate of ETS induced by FCCP is represented at three different levels of organisation: at the subcellular level (nmol O.min ${ }^{-1} . \mathrm{mg}^{-1}$ proteins $^{-1}$ ) obtained through respiration measurements of isolated mitochondria; at the red muscle fibre level $\left(\mathrm{pmol} \mathrm{O}_{2} \cdot \mathrm{s}^{-1} \cdot \mathrm{mg} \mathrm{muscle}^{-1}\right)$ obtained through respiration measurements of a red muscle sample, and at the red muscle level estimated by multiplying maximal respiration rate at the fibre level by red muscle mass or relative red muscle mass (total: $\mathrm{pmol} \mathrm{O}_{2} \cdot \mathrm{s}^{-1}$; specific: $\mathrm{pmol}_{2} \cdot \mathrm{s}^{-1} \cdot \mathrm{g}$ fish ${ }^{-1}$ ). Values are mean \pm s.e.m. The mitochondrial content of red muscle is expressed in milligram of mitochondrial proteins per gram of red muscle and was estimated as the ratio between respiration rates at the fibre level and mitochondrial level. Data were analysed with a linear mixed-effects model with size and quantity as fixed-effects and sex as random effect. Different letters indicate a significant difference among groups at $\mathrm{P}<0.05$. The boxes with the asterisks on the measurements indicates a global effect of item size $(* P<0.05 ; * * P<0.01)$.

856

\begin{tabular}{lcccccc} 
& LI-LQ & LI-SQ & SI-LQ & SI-SQ & Statistical analysis \\
\hline $\mathrm{N}$ & $9-11$ & $11-12$ & $9-11$ & $9-12$ &
\end{tabular}

Maximal respiration ETS activity

\begin{tabular}{|c|c|c|c|c|c|c|}
\hline \multicolumn{2}{|c|}{ Mitochondrial level (nmol O. $\min ^{-1} \cdot \mathrm{mg}$ protein ${ }^{-1}$ ) } & $90 \pm 9$ & $96 \pm 7$ & $59 \pm 12$ & $65 \pm 12$ & Size: $P=0.004$ \\
\hline \multicolumn{2}{|c|}{ Red muscle fibre level (nmol O.min ${ }^{-1} . \mathrm{mg}$ muscle $^{-1}$ ) } & $5 \pm 0.8^{\mathrm{a}}$ & $3.5 \pm 0.4^{\mathrm{a}}$ & $3.3 \pm 0.4^{\mathrm{a}}$ & $5.3 \pm 0.9^{\mathrm{a}}$ & Size* Quantity: $P=0.014$ \\
\hline \multirow[t]{2}{*}{$\begin{array}{l}\text { Red muscle } \\
\text { level }\end{array}$} & Total $\left(\mu \mathrm{mol} \mathrm{O} . \mathrm{min}^{-1}\right)$ & $6.3 \pm 0.9^{\mathrm{a}}$ & $4.4 \pm 0.7^{\mathrm{a}}$ & $3.6 \pm 0.7^{\mathrm{a}}$ & $4.1 \pm 0.8^{\mathrm{a}}$ & n.s. \\
\hline & Specific $\left(\mathrm{nmol} \mathrm{O} \cdot \mathrm{min}^{-1} \cdot \mathrm{g}\right.$ fish $\left.^{-1}\right)$ & $350 \pm 44^{\mathrm{a}}$ & $306 \pm 38^{\mathrm{a}}$ & $245 \pm 34^{\mathrm{a}}$ & $307 \pm 58^{\mathrm{a}}$ & n.s. \\
\hline \multicolumn{2}{|c|}{ Mitochondrial content (mg protein. $\mathrm{g}$ muscle $\left.{ }^{-1}\right)^{\mathrm{X}}$} & $50.9 \pm 7.7$ & $34.8 \pm 5.4$ & $52.6 \pm 8.2$ & $62.2 \pm 7.6$ & Size: $P=0.040$ \\
\hline
\end{tabular}
857 